\title{
PENINGKATAN PARTISIPASI PETANI, PEMBERDAYAAN KELEMBAGAAN DAN KEARIFAN LOKAL MENDUKUNG KETAHANAN PANGAN BERKELANJUTAN
}

\author{
Roosganda Elizabeth \\ Pusat Sosial Ekonomi dan Kebijakan Pertanian. Jl. Tentara Pelajar No. 3B. Cimanggu. \\ Bogor
}

\begin{abstract}
Abstrak
Tulisan ini bertujuan untuk mengemukakan pentingnya peningkatan partisipasi petani, pemberdayaan kelembagaan dan kearifan lokal dalam pengadaan dan ketersediaan pangan mendukung ketahanan pangan berkelanjutan. Seiring peningkatan pertumbuhan penduduk yang rata-rata mencapai kisaran $1,49 \%$ menyebabkan peningkatan permintaan pangan, sementara pertumbuhan ekonomi sekitar 6-7\% dan pendapatan pangan yang masih elastis. Perlunya antisipasi anomali iklim ekstrem, tingginya degradasi dan pengendalian konversi lahan, dan berbagai kendala terkait lainnya diprediksi penyebab relatif rendahnya kapasitas dan ketersediaan pangan; yang membutuhkan keberpihakan dan pendampingan berbagai pihak terkait dalam pelaksanaan berbagai inovasi teknologi pertanian. Peningkatan dan pemberdayaan peran kelembagaan pertanian merupakan salah satu strategi pemerintah untuk mendukung kemandirian dan ketahanan pangan berkelanjutan. Diperlukan segera antisipasi penanganan pemenuhan pangan dengan meningkatkan partisipasi petani dalam pemberdayaan berbagai kelembagaan pertanian terkait dan kearifan lokal. Perlunya pendekatan dan pengkajian berbagai Undang-undang dan regulasi terkait serta pendampingan yang lebih serius, mendalam dan berkelanjutan untuk mengurus pengadaan dan ketersediaan pangan untuk mewujudkan kemandirian pangan menuju ketahanan pangan berkelanjutan.
\end{abstract}

Kata kunci: partisipasi petani, pemberdayaan kelembagaan, kearifan lokal, ketahanan pangan.

\begin{abstract}
This paper aims to highlight the importance of increasing farmer participation, institutional empowerment and local wisdom in the procurement and availability of food to support sustainable food security. As population growth increases, which on average reach $1.49 \%$, it causes an increase in food demand, so that various problems must be overcome in an effort to realize food security because the increase in food availability is still lower than demand growth, while economic growth is around 6-7\% and income food that is still elastic. The occurrence of extreme climate anomalies, high levels of uncontrolled degradation and land conversion, and various other related constraints are predicted to greatly affect and be one of the causes of relatively low food capacity and availability. It is necessary to immediately support the various parties involved in the implementation of various agricultural technological innovations to anticipate the handling of food fulfilment with and increase the participation of farmers in the empowerment of various related agricultural institutions and local wisdom. The need for an approach and study of various relevant laws and regulations as well as more serious, in-depth and sustainable assistance to take care of the procurement and availability of food to realize food independence towards national food security.
\end{abstract}

Keywords: farmer participation, institutional empowerment, local wisdom, food security 


\section{Pendahuluan}

Partisipasi petani dan pemberdayaan kelembagaan pertanian merupakan aspek penting program pembangunan di pedesaan, dimana pemberdayaan petani dalam konteks kelembagaan merupakan target yang hendak dicapai, dan partisipasi petani sebagai alat untuk mencapai target (tujuan) tersebut. Dalam partisipasi, siapapun dapat berperan aktif, baik berperan dalam bermasyarakat, dalam kehidupan sendiri, terlebih lagi keterlibatan untuk berperan dalam pembangunan. Peran partisipasi (dalam pembangunan pertanian) merupakan proses dimana seluruh pihak (langsung/tidak langsung) dapat membentuk/membangun kondisi kondusif dan turut serta terlibat serta kooperatif dalam seluruh inisiatif, tahapan dan aktivitas pembangunan. Salah satunya pada tercapainya keberhasilan suatu program pembangunan pertanian yang didukung penuh oleh partisipasi petani, para pelaksana di lapang dan kesesuaian pelaksanaan di lapang dengan target tujuan pelaksanaan. Untuk mengatasi dan mengantisipasi berbagai permasalahan usahatani, pemerintah berupaya meningkatkan partisipasi pelaku usaha pertanian dan eksisnya peran dan fungsi kelembagaan pertanian.

Disamping itu, juga mampu mengadaptasi inovasi teknologi spesifik lokasi serta kearifan lokal, yang menunjukkan keberpihakan dan keseriusan pemerintah dalam membangun suatu daerah terutama pedesaan. Kearifan lokal merupakan pengetahuan, pengalaman dan kemampuan warisan dan mendasar suatu daerah, yang bila dikembangkan akan sangat bermanfaat sebagai pendukung kesuksesan program pembangunan di daerah tersebut dan sudah selayaknya untuk diberdayakan dan dikembangkan. Keberhasilan tersebut teridentifikasi pada ada dan terlibatnya pemberdayaan dan peningkatan peran, fungsi dan kinerja kelembagaan pelaksana program serta pentingnya mengikutsertakan fungsi dan peran kearifan lokal. Tulisan ini bertujuan untuk mengemukakan secara deskriptif kualitatif tentang pentingnya peningkatan partisipasi petani, pemberdayaan kelembagaan dan kearifan lokal dalam pengadaan dan ketersediaan pangan mendukung ketahanan pangan berkelanjutan. Cakupan wawasan tulisan diperkaya dengan mereview berbagai hasil kajian dan literature terkait lainnya.

Penambahan ketersediaan pangan masih lebih rendah dibanding pertumbuhan permintaannya, sementara pertumbuhan ekonomi sekitar 6-7\% dan pendapatan pangan yang masih elastis. Peningkatan pertumbuhan penduduk yang rata-rata mencapai kisaran 1,49\% (BPS, asumsi 5 tahun terakhir, data series) menyebabkan peningkatan permintaan pangan, memunculkan berbagai permasalahan dalam upaya mewujudkan ketahanan pangan. Diantaranya, terjadinya: anomali iklim ekstrem, tingginya degradasi dan konversi lahan yang tidak terkendali, dan berbagai kendala lainnya diprediksi sangat mempengaruhi dan menjadi salah satu penyebab relatif rendahnya kapasitas dan ketersediaan pangan. Meningkatnya peran dan partisipasi petani untuk mendukung pemberdayaan fungsi dan peran kelembagaan pertanian serta SDM dan kinerja petani yang berusahatani berdasar spesifik lokasi dan tetap mengandalkan kearifan lokal. Salah satunya tercermin pada meningkatnya produksi dan produktivitas usahatani dengan tujuan mewujudkan ketahanan pangan berkelanjutan dan sangat mempengaruhi pendapatan petani; dimana ketahanan pangan berkelanjutan menjadi salah satu tujuan program pembangunan berkelanjutan.

\section{Metode Penelitian}

Kondisi yang dihadapi oleh petani tradisional (swadaya) umumnya masih bersifat sporadik dan belum terorganisir dengan baik. Namun petani lebih fokus kepada lingkungan dan konservasi hayati dalam konteks fisik, biologis, dan sosial 
(Wilken, 1990; Altieri, 2004).

Pada aspek lainnya seperti profesionalitas pengelolaan organisasi, kapasitas SDM, pencatatan, pengaturan tatakelola ke dalam (terhadap anggota) dan ke luar masih relatif lemah, serta terpingginrnya peran kearifan lokal. Masih relatif berfluktuasinya produksi dan produktivitas usahatani, sangat mempengaruhi ketersediaan dan kontiniutas bahan pangan. Hal tersebut tentu sangat mempengaruhi kemampuan pemenuhan pangan, yang berakibat pada terkendalanya perwujudan kemandirian dan ketahanan pangan. Tinggi rendahnya perolehan hasil usahatani juga sangat berpengaruh pada pendapatan pelaku usaha/produsennya yaitu petani itu sendiri (Mosher, 1978).

Tulisan ini bertujuan mengemukakan pentingnya peningkatan partisipasi petani (Pranadji, 2016), pemberdayaan kelembagaan dan kearifan lokal dalam pengadaan, kontiniutas dan ketersediaan pangan mendukung ketahanan pangan berkelanjutan; yang dilakukan dengan metode deskriptif kualitatif.

Pengayaan cakupan dan wawasan tulisan dilakukan dengan mereview berbagai hasil penelitian dan literature terkait lainnya. Pencapaian produksi dan produktivitas suatu usahatani tentunya seiring dengan ketersediaan dan kemampuan SDM petaninya yang dipengaruhi oleh kapasitas kearifan lokal yang dimilikinya, dalam mengadopsi dan mengaplikasikan teknologi pertanian beserta inovasinya. Aplikasi teknologi dan inovasinya dapat diterapkan dengan adanya partisipasi petani dan peran aktif kelembagaan pertanian, serta melibatkan kearifan lokal suatu daerah dalam pelaksanaannya. Untuk itu, partisipasi petani dibutuhkan untuk keberhasilan pemberdayaan kelembagaan pertanian dan SDM petani dengan pendampingan yang berkelanjutan, sebagai penguatan intensif sehingga dapat berperan sebagaimana mestinya.baik dalam bentuk koperasi, kelompok tani, atau badan usaha bersama lainnya.

\section{Hasil dan Pembahasan}

\section{Perspektif Kinerja Program Pembangunan Nasional di Era Globalisasi}

Sampai saat ini, sektor pertanian tetap mengalami pertumbuhan positif, dimana pertumbuhan ekonomi malah sedang mengalami pelandaian meski tetap mengalami kenaikan walau sedikit (Arifin 2004), namun belum sesuai harapan dan gencarnya dilakukan berbagai program pembangunan di sektor lainnya. Kondisi tersebut membuktikan bahwa sektor pertanian ternyata mampu bertahan dan mampu terus sebagai penahan untuk mengembangkan perekonomian Indonesia di masa yang akan datang. Derasnya arus globalisasi membuat Indonesia harus terus mengembangkan dan memajukan sektor pertaniannya agar mampu mempercepat pertumbuhan ekonomi dan meningkatkan perekonomian nasional; sehingga. Perlu ditelaah strategi pembangunan dalam era globalisasi. Di masa yang lalu, strategi pembangunan bertumpu pada Trilogi Pembangunan, pemerataan dan stabilitas, yang secara konsepsional baik, namun dalam pelaksanaannya terjadi banyak kesalahan (Asnudin, 2010).

Pertumbuhan sektoral yang tinggi pada sektor industri ternyata tidak mampu menyerap tenaga kerja secara berarti. Sektor industri yang dikembangkan bersifat padat modal dan tidak cocok diterapkan di Indonesia, karena pada kenyataannya sebagai negara agraris tenaga kerja kebanyakan masih berada pada sektor pertanian. Pencapaian stabilitas nasional bersifat semu, dipenuhi nuansa yang sekedar tunduk pada perintah petinggi negara, sehingga memunculkan euphoria anarkisme. Perubahan pola pembangunan melalui strategi trickle down effect yang bertujuan membawa kenaikan pendapatan masyarakat lapisan bawah (mayoritas), namun tidak berhasil dan menimbulkan berbagai masalah 
karena kurangnya pembangunan dan pemberdayaan kelembagaan yang benar.

Untuk menghadapi persaingan di era globalisasi, dicanangkanlah strategi pembangunan pertanian berkelanjutan. Sebagai negara agraris, maka titik tolak pembangunan harus bertumpu kembali pada pertanian, sehingga perlu diwujudkan strategi pembangunan pertanian yang terdiri dari subsektor penyedia input, subsektor produksi, dan subsektor output (dari hulu hingga hilir). Strategi pembangunan pertanian berkelanjutan dimulai dari hulu hingga hilir yang memposisikan pentingnya peningkatan dan pengembangan: (i) kelembagaan pertanian; (ii) kompetensi dan kinerja SDM pertanian; (iii) bantuan dana/permodalan usahatani; (iv) pola kemitraan; (v) perwilayahan komoditas usahatani; (vi) kelestarian SDA dan lingkungan (SDGs).

Penjabaran strategisnya kelima posisi tersebut dalam mencapai keberhasilan pembangunan pertanian berkelanjutan, dimana: pemberdayaan kelembagaan pertanian agar fungsi dan perannya dapat memenuhi semua kebutuhan dan aspek kegiatan pertanian, termasuk pasca panen dan pemasaran. Melihat kondisi keterbatasan kompetensi dan kinerja SDM pertanian pemerintah mengupayakan pelatihan, penyuluhan dan pendampingan yang harus menyeluruh dan terpadu serta berjalan serasi dengan semua aspek yang menyangkut usahatani dan agribisnis, seperti, aspek: teknis, pemasaran, pembukuan, permodalan, asuransi, dan berbagai aspek lainnya. Bantuan dana dan permodalan diperlukan (termasuk saprodi), untuk menggairahkan kinerja usahatani dan pengembangan agribisnis di Indonesia. Dengan pembangunan pertanian berkelanjutan semua subsektor yang saling terkait dan terintegrasi, baik sektor input, produksi, maupun output, yang diarahkan untuk menggunakan sumberdaya (bahan baku) dari dalam negeri, merupakan langkah strategis untuk mencapai ketangguhan perekonomian Indonesia.

Keberpihakan lembaga keuangan terhadap permodalan usahatani dan keterbatasan pemilikan petani untuk jaminan pinjamannya. Penentuan suatu kawasan perwilayahan komoditas didasarkan pada: (i) kesesuaian dayadukung SDA untuk komoditi pertanian bersangkutan (kondisi tanah secara keseluruhan, sumberdaya air dan iklim dengan teknologi spesifik lokasi; (ii) potensi sumberdaya buatan yang ada dan yang dapat dikembangkan; dan (iii) potensi sumberdaya manusia, baik dari jumlah maupun kualitas SDM di lokasi, serta memperhitungkan peran kearifan lokal). Pola kemitraan antar pihak-pihak terkait merupakan upaya untuk dapat saling menguntungkan. Peran koperasi sangat diperlukan dalam rangka mengembangkan ketahanan sektor pertanian, serta memperkuat posisi petani dalam menjual hasil produk pertaniannya. Penerapan kelestarian SDA dan lingkungan (SDGs) merupakan keterpaduan dengan seluruh konsep pembangunan pertanian yang berkelanjutan.

Untuk merealisasikannya tercermin dibutuhkan partisipasi aktif SDM pertanian (petani dan pelaku usaha pertanian terkait lainnya), pemberdayaan kelembagaan dan kearifan lokal, mendukung ketahanan pangan berkelanjutan. Dengan strategi pembangunan pertanian melalui pemberdayaan manusia, bantuan dana keuangan, pola kemitraan dan perwilayahan komoditis akan menghasilkan perekonomian Indonesia yang lebih baik.

\section{Partisipasi Petani, Pemberdayaan Kelembagaan dan Kearifan Lokal Mendukung Ketahanan Pangan Berkelanjutan}

Partisipasi penting bagi beragam pelaku usaha, terutama pelaku usahatani (petani) dalam setiap tahapan aktivitas usahataninya hingga pengelolaan pasca panen dan 
pemasaran. Dalam partisipasi, siapapun dapat berperan aktif, baik berperan dalam bermasyarakat, dalam kehidupan sendiri, terlebih lagi keterlibatan untuk berperan dalam pembangunan. Masih kuatnya sentimen individu dalam kelompok, membutuhkan partisipasi sebagai sarana untuk menunjukkan kerjasama dan kemampuan merespon perkembangan dan inovasi teknologi, dan mampu beradaptasi dengan kemajuan pembangunan. Seluruh pihak terkait, secara langsung/tidak langsung) dapat membentuk/ membangun kondisi dan turut serta terlibat serta kooperatif dalam seluruh inisiatif, tahapan dan aktivitas pembangunan.

\section{Makna Partisipasi dan Kinerja yang diharapkan dari Partisipatif}

Partisipasi (peran serta/peran aktif) masyarakat tani dalam proses pembangunan pertanian diharapkan dan diupayakan dimulai dari perencanaan, pelaksanaan hingga monitoring dan evaluasi. Peran serta tersebut mengindikasikan upaya untuk mewujudkan kemandirian suatu daerah yang transparan dan akuntabel menyangkut berbagai aspek/faktor dan pihak yang terkait satu sama lain. Berbagai faktor tersebut merupakan komponen pemerintah, masyarakat, dan swasta dengan berbagai aspek kepentingan masing-masing. Keterkaitannya dilandasi aturan kebijakan untuk saling berpartisipasi sesuai kompetensi dan proporsi yang dimiliki secara terukur, teratur dan berkelanjutan. Dalam hal ini, makna partisipatif yang paling sederhana adalah merupakan hak setiap orang untuk dapat ikut serta dan secara aktif terlibat atau dilibatkan dalam pembangunan, dalam setiap prosesnya, melibatkan seluas-luasnya stake holders (pemangku kepentingan) yang ada dalam setiap kebijakan publik, dan yang tidak hanya sebatas lembaga formal semata. Kondisi tersebut dapat berlangsung dan kondusif, dengan mengutamakan dan merupakan prinsip-prinsip dasar good governance (pemerintahan yang baik), yaitu: (1) partisipatif; (2) transparansi; (3) akuntabilitas. Hal tersebut dimaksudkan agar dapat menangkap dan menjembatani antara pemerintah (pembuat dan pelaksana program) terhadap aspirasi dan kebutuhan masyarakat tani di pedesaan.

Partisipasi dalam konteks pembangunan agar keberlanjutan diupayakan bermula dari proses community driven, community led dan community owned. Terkait dengan partisipasi masyarakat pelaku berbagai ragam usaha, terutama pelaku usahatani (petani), pelaku bioindustri dan agribisnis, peran dan makna partisipasi (dalam pembangunan) merupakan proses dan keadaan (situasi). Disamping itu, dengan makna partisipatif juga diharapkan dapat menggugah kesadaran publik bahwa terjadinya keberhasilan maupun kegagalan proses pembangunan pertanian di perdesaan bukan tanggung pemerintah semata, melainkan sangat bergantung pada keberhasilan keterlibatan petani (dan masyarakat) dalam proses pembangunan pertanian tersebut, mulai dari awal sampai akhir, sehingga tercapai tujuan untuk meningkatkan kesejahteraan petani dan masyarakat pedesaan. Diprediksi terdapat sedikitnya tujuh karakteristik tipologi partisipasi, yang berurutan untuk makin mendekati bentuk ideal, yaitu partisipasi: 1) Pasif atau manipulatif; 2) Informatif; 3) Konsultatif; 4) Insentif; 5) Fungsional; 6) Interaktif; 7) (self mobilization).

Partisipasi pasif atau manipulatif merupakan bentuk partisipatif yang paling lemah, pengumuman hanya sepihak, dari pelaksana proyek, informasi terbatas di kalangan professional, mengabaikan tanggapan masyarakat sebagai sasaran program. Pada partisipasi informatif, akurasi hasil studi tidak dibahas bersama masyarakat. Masyarakat pasif, hanya merespon pertanyaan untuk proyek, tanpa terlibat dalam proses keputusan. Pada partisipasi konsultatif, masyarakat hanya berkonsultasi 
dan mendengarkan, belum berpeluang membuat keputusan bersama karena pelaksana tidak berkewajiban menindaklanjuti masukannya. Pada partisipasi insentif, masyarakat hanya memperoleh imbalan insentif/upah atas jasanya, tidak dilibatkan dalam proses kegiatan pembangunan setelah insentif dihentikan. Pada partisipasi fungsional, masyarakat mulai menunjukkan kemandiriannya, dengan membentuk kelompok menjadi bagian proyek setelah ada kesepakatan atas keputusan-keputusan utama. Pada partisipasi interaktif, masyarakat berperan dalam proses analisis untuk perencanaan kegiatan dan pembentukan/ penguatan kelembagaan, berperan mengontrol pelaksanaan keputusan dan keseluruhan proses kegiatan; cenderung melibatkan metode interdisipliner untuk mencari keragaman perspektif dalam pembelajaran yang terstruktur dan sistematis. Pada partisipasi yang sudah mandiri (self mobilization), masyarakat bebas untuk berinisiatif dan melakukan kontak dengan pihak/lembaga lain terkait dukungan teknis, bantuan dan sumberdaya yang dibutuhkan.

Pada masyarakat lokal juga terdapat enam bentuk partisipasi yang secara berurutan ke yang semakin baik, dan tidak berbeda jauh dengan ke tujuh karakteristik tipologi partisipasi sebelumnya, yaitu: bentuk partisipasi: co-option; co-operation; consultation; collaboration; co-learning; dan collective action. Meski memiliki makna yang berbeda-beda (tergantung pada "apa" dan "bagaimana" mereka turut serta terlibat), namun pada akhirnya partisipasi bertujuan untuk increasing self-determination (meningkatkan kemandirian/ keteguhan diri), serta terkontruksinya/ terbangunnya kontrol (build construction control), ikut serta dan berperannya inisiatif masyarakat terhadap pengelolaan sumberdaya untuk pembangunan. Dalam partisipasi, siapapun dapat berperan aktif, baik berperan dalam bermasyarakat, dalam kehidupan sendiri, terlebih lagi keterlibatan untuk berperan dalam pembangunan. Dengan partisipatif, diharapkan dapat menggugah kesadaran publik bahwa tercapainya keberhasilan maupun terjadinya kegagalan proses pembangunan pertanian di pedesaan sangat bergantung pada keberhasilan keterlibatan dan keikutsertaan masyarakat petani secara aktif dan nyata.

Peran aktif (partisipasi) sangat mempengaruhi terwujudnya keberhasilan berbagai program kebijakan, terutama berkat peran SDM pelaku pelaksana dan SDM targetnya. Peran dan pengaruh tersebut akan lebih baik hasilnya dan berdayaguna apabila petani secara berkelanjutan mendapat informasi, bimbingan dan pelatihan inovasi teknologi tepat guna, yang diperoleh baik melalui kelompok tani maupun melalui penyuluhan dan pendampingan aktif serta berkesinambungan. Dalam penyelenggaraan pembangunan, terutama dalam upaya meningkatkan kesejahteraan masyarakat petani, bukanlah hanya tanggungjawab pemerintah semata, melainkan membutuhkan bahkan mengharuskan keterlibatan dan partisipasi aktif semua pihak terkait, terutama masyarakat petani itu sendiri. Partisipasi merupakan hak dan tindakan setiap orang, termasuk stake holders, yang terdapat dalam setiap program pembangunan dan kebijakan publik, untuk ikut serta berperan aktif dalam proses pembangunan.

Untuk memperkuat partisipasi, diperlukan penumbuhan kesadaran dan pengorganisasian kelembagaam masyarakat, yang ditempuh dengan berbagai upaya, seperti: public hearing, workshop, focus group discussion/ FGD, menyusun kelembagaan sebagai wadah penyampai input publik, adanya media untuk mendiskusikan berbagai isu dan perhatian, serta iklim yang kondusif dan demokratis. Partisipasi sangat penting untuk terjaminnya 
pembangunan berkelanjutan yang sangat tergantung pada social process yang mengintegrasikan tiga aspek utama masyarakat, yaitu: sosial, ekonomi dan lingkungan. Partisipasi individu dan kelompok petani, masyarakat dan kelembagaan yang saling berperan dan terkait untuk terjadinya perubahan menuju peningkatan sebagai tujuan pembangunan yang harus responsif terhadap rakyat. Melalui partisipatif, sentimen individu yang masih kuat dalam kelompok diberdayakan untuk merespon perkembangan teknologi, menumbuhkan kemampuan petani mengadaptasi dan melaksanakan setiap tahapan program pembangunan. Sebagai pegangan, pemantau dan pengawal dalam terlaksana dan suksesnya suatu program pembangunan, diperlukan partisipasi dalam monitoring dan evaluasi yang berupaya melibatkan (to engage) pihak-pihak stakeholders utama untuk lebih aktif dalam merefleksikan dan mengukur (assesing) kemajuan proyek dan terutama pencapaian hasil.

\section{Pemberdayaan Kelembagaan, Kearifan Lokal:}

Mendukung Terwujudnya Ketahanan Pangan Berkelanjutan

Pencapaian dayasaing menjadi kunci utama untuk meraih peluang pasar domestik dan global di era liberalisasi perdagangan dan perekonomian. Peningkatan efisiensi dan kualitas produk untuk mendayagunakan secara optimal potensi pasar, yang dapat dilakukan adalah peningkatan perbaikan sistem produksi, pascapanen dan pengolahan, yang tentunya membutuhkan kompetensi SDM yang berkemampuan dan handal, termasuk petani (produsen), dan fungsi serta peran aktif (partisipasi) kelembagaan pertanian. Namun, semakin kuatnya penetrasi dan tekanan ekonomi global ke pedesaan, yang diprediksi sarat dengan nuansa kapitalis, diantaranya dalam bentuk penerapan teknologi modern (modernisasi pertanian) dan sistem pasar yang mengutamakan efisiensi dengan memaksimalisasi relasi untuk meminimalisir kendala. Relasi dan ekonomi uang menyebabkan makin lemahnya peran lembaga tradisional; dimana sifatnya yang dipandang involutif karena lebih mengutamakan hubungan produksi dalam bentuk resiproritas. Hal tersebut menyebabkan semakin longgarnya norma dan nilai ikatan sosial yang terjalin dalam kelembagaan pedesaan. Disisi lain, dengan berkembangnya kecenderungan yang bersifat involutif tersebut dalam prinsip ekonomi uang dewasa ini, yaitu dalam hubungan yang lebih menekankan bentuk pertukaran (resiprositas), pada kenyataannya semakin melemahkan peran kelembagaan tradisional di pedesaan.

\section{Makna dan Peran Penting Kearifan Lokal}

Konsep pembangunan dan pertumbuhan yang berorientasi ekonomi selain berdampak pada peningkatan laju pertumbuhan ekonomi bangsa, namun secara tidak sengaja juga menyebabkan timbulnya ketergantungan yang cukup tinggi terhadap pemerintah. Ketergantungan tersebut sekaligus mematikan nilai-nilai lokal petani dalam pembangunan pertanian. Nilai-nilai lokal (termasuk pengalaman dan pengetahuan/kearifan lokal/local wisdom) tersebut digantikan oleh jargon ekonomi global yang meniadakan hubungan manusia dengan ekosistem alam sebagai hubungan yang simetris dan bukan saling ketergantungan satu sama lain (Mahmuddin. 2013). Kondisi meniadakan peran kearifan lokal tersebut memunculkan stigma dari banyak pihak untuk memikirkan ulang pola pembangunan pertanian yang tidak hanya menguntungkan bagi pelaku sendiri (petani), namun pola yang sekaligus juga mampu membangun hubungan sinergis aspek ekonomi, sosial dan lingkungan dengan ikut serta dan berperannya kearifan lokal dalam pembangunan pertanian.

Terkait kearifan lokal, hubungan interdependensi atau kemitraan kelembagaan pertanian yang terbentuk 
mencirikan interaksi yang sangat asimetris, sehingga dinilai tidak menguntungkan bagi perbaikan kualitas ketenagakerjaan (SDM) petani. Hal tersebut mencerminkan sentralistik kebijakan perancang pembangunan (top down), centrally planned economies (Kozminski, 1990; dalam: Elizabeth, 2008) dan monolitik, sehingga terkesan sulit berkembang dan tidak mengakar pada adat, kebudayaan dan local wisdom sebagai local knowledge masyarakat setempat. Untuk memperbaiki kondisi tersebut diperlukan pengembangan dan pemberdayaan kelembagaan tradisional, yang dimulai dari earifan lokal masyarakatnya agar menjadi esensial untuk mencapai kesinergisan optimum dalam aktivitasnya di tingkat lokal; membantu peningkatan ke arah industrialisasi; dan memudahkan petani mengembangkan sistem kelembagaan agribisnis (Elizabeth. 2015).

Kearifan lokal di suatu daerah, merupakan aset dalam mewujudkan keberhasilan pembangunan pertanian. Di setiap daerah tentunya memiliki kekhasan masing-masing dalam mengelolah SDA-nya, terkait budaya, adat istiadat dan kebiasaan penduduk setempat, pengalaman dan pengetahuan yang telah diwarisi turun temurun sejak dulu, yang sederhananya dimaknai sebagai kearifan lokal suatu daerah. Kearifan lokal juga merupakan norma dan nilai yang terdapat dalam ikatan dan kehidupan sosial di masing-masing daerah, yang terjalin dalam ikatan kelembagaan yang eksis dan berperan dalam berbagai sendi kehidupan di daerah tersebut. Dari berbagai aplikasi teknologi dan inovasi usahatani dalam pelaksanaan program pembangunan pertanian yang telah terlaksana, sedikit tidaknya tentu dipengaruhi oleh kebiasaan, pengalaman, adat istiadat dan budaya penduduk setempat. Hal ini yang mengindikasikan berperannya suatu kearifan lokal di masing-masing daerah.

Fungsi dan peran kearifan lokal sangat mempengaruhi keberhasilan pemberdayaan dan peningkatan peran, fungsi dan kinerja kelembagaan pertanian. Dengan mempertimbangkan peran kearifan lokal (local wisdom), yang pengaplikasiannya dibarengi ketrampilan dan kompetensi SDM petani (masyarakat) yang telah dilatih dengan pendampingan yang berkelanjutan agar selaras dengan kemajuan dan inovasi teknologi perkembangan di masa kini. Niscaya dengan keikutsertaan fungsi, peran dan pengaruh kearifan lokal tersebut, maka tercapainya keberhasilan pembangunan pertanian akan lebih baik hasilnya dan berdayaguna terlebih bila diikutsertakan secara berkelanjutan. Pengembangan teknologi, investasi dan SDM petani dan pelaku usaha terkait melalui pengembangan dan permberdayaan kelembagaan pertanian pedesaan dan kearifan lokal di masingmasing daerah. Perkembangan tersebut diprediksi mampu menjadi "mesin penggerak" kemajuan ekonomi yang tangguh, terutama bila pemberdayaan dan pengembangan kelembagaannya berfungsi sejalan dengan program kebijakan pembangunan yang dilaksanakan.

\section{Pentingnya Peran Aktif Pemberdayaan dan Keberpihakan Kelembagaan}

Peningkatan dan pemberdayaan peran kelembagaan pertanian merupakan salah satu strategi pemerintah untuk mendukung kemandirian dan ketahanan pangan berkelanjutan. Pemberdayaan dan pengembangan kemampuan SDM petani dalam menghasilkan produk usahatani melalui fungsi dan peran berbagai kelembagaan pertanian, termasuk lembaga pasca panen dan pemasarannya. Peran dan pengaruh kemampuan kelembagaan SDM dan kinerja petani akan lebih baik hasilnya dan berdayaguna apabila petani secara berkelanjutan mendapat informasi, bimbingan dan pelatihan inovasi teknologi tepat guna, yang diperoleh baik melalui kelompok tani maupun melalui penyuluhan dan pendampingan aktif serta berkesinambungan. Lembaga di pedesaan 
lahir untuk memenuhi kebutuhan sosial masyarakatnya (Elizabeth, 2008). Sifatnya tidak linier, namun cenderung merupakan kebutuhan individu anggotanya, antara lain berupakebutuhan: fisik, rasa aman (savety), hubungan sosial (social affiliation), pengakuan (esteem), pengembangan pengakuan (self actualization) (Elizabeth, 2007b). Berbagai aspek kelembagaan pertanian di perdesaan perlu dibenahi dalam
Pemberdayaan dan pengembangan kelembagaan di perdesaan terkait pengembangan agribisnis adalah: tenaga kerja (SDM) dan pemasaran, terutama dalam implementasi teknologi inovatif pascapanen, mutlak dijadikan fokus utama dalam perancangan kebijakan pemerintah dan diperlukan untuk terwujudnya agribisnis, serta untuk memecahkan masalah ekonomi masyarakat

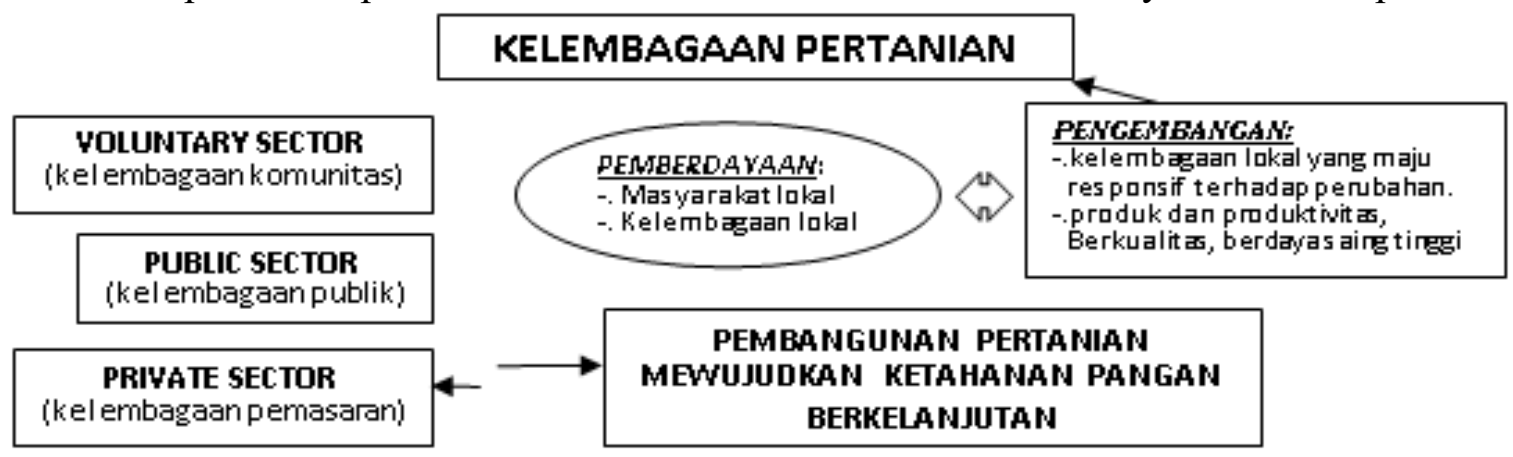

Gambar 1. Berbagai Kelembagaan Pertanian Perdesaan, Pembangunan Pertanian, Mewujudkan ketahanan Pangan Berkelanjutan

mendukung proses pengembangan pertanian dan kemajuan pedesaan. Salah satunya harus mampu berperan dalam penyerapan dan produktivitas kelembagaan tenagakerja, dan memperluas jangkauan kelembagaan pemasaran menuju peningkatan agribisnis produk usahatani, melalui kajian deskriptif.

Lembaga di pedesaan lahir untuk memenuhi kebutuhan sosial masyarakatnya (Elizabeth, 2008). Sifatnya tidak linier, namun cenderung merupakan kebutuhan individu anggotanya, antara lain berupakebutuhan: fisik, rasa aman (safety), hubungan sosial (social affiliation), pengakuan (esteem), pengembangan pengakuan (self actualization) (Elizabeth, 2007b).

Terdapat empat elemen kunci dalam pengembangan kelembagaan pertanian dan agribisnis perdesaan, yaitu: 1) aglomerasi perusahaan (cluster); 2) peningkatan nilai tambah (value added) dan mata rantai nilai (value chain); 3) jaringan pemasok dan pelanggan; dan 4) jaringan infrastruktur ekonomi fisik dan non fisik (Elizabeth. 2015).
Kelembagaan di perdesaan dapat dikategorikan antara lain dalam: administrasi lokal; pemerintah lokal; organisasi/kelembagaan lokal, kerjasama usaha, pelayanan dan bisnis swasta (agribisnis) yang dapat diintegrasikan ke dalam pasar baik lokal, regional dan global (Uphoff. 1992; dalam: Elizabeth. 2016; 2017; 2018). Dalam perencanaan dan pelaksanaan pembangunan perdesaan, hendaknya ditekankan perbaikan dan pembenahan ragam kelembagaan yang berdayaguna dan berhasilguna serta ke arah peningkatan pendapatan, kesempatan kerja dan berusaha di perdesaan. Sebagai penghela pembangunan pertanian, agribisnis diharapkan mampu menciptakan berbagai produk pertanian dan produk olahannya, mampu memotori pemasaran hasil usahatani untuk pengembangan perekonomian perdesaan, serta mampu menciptakan lapangan kerja dan pendapatan di perdesaan. Beberapa kendala dalam mencapai keberhasilan pembangunan pertanian meliputi: (i) belum berperan aktifnya atau bahkan belum tersedianya kelembagaan pertanian; (ii) belum 
berkembangnya teknologi dan inovasi usahatani karena masih kecil dan terbatasnya sumber permodalan; (iii) masih relatif rendahnya kualitas SDM dan belum professional; (iv)sarana dan prasarana belum memadai; (v) rendahnya jaminan mutu dan kontiniutas (ketersediaan) bahan baku; (vi) kelembagaan pemasaran belum berkembang karena produk industri pengolahan pertanian belum memenuhi persyaratan pasar, khususnya pasar internasional; (vii) belum adanya kebijakan riil maupun peraturan/regulasai yang mendorong berkembangnya agribisnis di dalam negeri.

Pelaksanaan peningkatan dan pemberdayaan fungsi dan peran kelembagaan pertanian dan perdesaan merupakan salah satu aspek program pembangunan pertanian yang semestinya berkesinambungan dan berkelanjutan. Salah satunya diimplementasikan terutama pada lembaga pemasaran melalui penguatan aspek bargaining position petani. Pemberdayaan dan pengembangan kelembagaan pemasaran perlu dilakukan untuk mengurangi perilaku spekulasi dari pedagang pengumpul yang secara aktif bahkan agresif mengambil dan menguasai hasil panen petani untuk pemasaran dan didistribusikan ke wilayah di dalam/luar lokasi usahatani. Hal tersebut mengakibatkan pasokan suatu produk di wilayah wilayah akan defisit/mengalami kekurangan. Untuk itu, dibutuhkan kelembagaan kemitraan pemasaran, agar diperoleh kesepakatan harga yang mampu mengantisipasi keuntungan bagi petani (bargaining position). Karena dengan kedinamisan dan relatif tingginya fluktuasi harga produk usahatani tersebut, dimana ketika harga komoditi di pasar mengalami kenaikan, maka selisih kenaikan harga tersebut dibagi secara proporsional antara kelompok tani mitra dengan perusahaan pengumpul. Sedangkan pada saat harga anjlok petani memperoleh perlindungan nilai komoditi dengan harga pembelian sesuai dengan kesepakatan. Tantangan yang dihadapi dalam pengembangan kemitraan pemasaran tersebut adalah penumbuhan kelembagaan sebagai wadahnya, sehingga diperlukan pendampingan yang intensif. Kepentingan masing-masing petani yang beragam dapat menjadi tantangan sekaligus peluang dalam penyadaran petani untuk berkelompok.

Meningkat dan eksisnya kelembagaan pertanian mencerminkan kemampuan SDM dan kinerja petani, yang sangat mempengaruhi besar kecilnya pendapatan petani. Dengan memahami deskripsi dan makna serta tujuan pemberdayaan dan pengembangan kelembagaan perdesaan, diharapkan menjadi landasan pemikiran dalam mengkaji pengembangan agribisnis di perdesaan, dalam rangka terciptanya struktur perekonomian yang seimbang dan berimbang di perdesaan. Berbagai sasaran dalam pengembangan agribisnis, seperti: terciptanya nilai tambah dan lapangan kerja, terserapnya sejumlah tenaga kerja, peningkatan pengetahuan dan keterampilan SDM dalam teknologi pengolahan, terbukanya peluang usaha berbahan baku produk pertanian, meningkatnya akses terhadap informasi di luar desa, mampu memotori agribisnis pedesaan, meningkatnya pertumbuhan ekonomi, peningkatan pembagian dan penyebaran pendapatan, peningkatan penerimaan devisa, serta perbaikan kelembagaan pasar sehingga mampu meraih dan memperluas jangkauan pemasaran (Elizabeth. 2017). Penguatan fungsi, peran dan jaringan kelembagaan berbasis sumberdaya pertanian yang menangani teknologi dan inovasi usahatani dengan pemberdayaan kelembagaan masyarakat tani merupakan salah satu faktor penting dan penunjang dalam mendukung pengembangan pertanian di perdesaan (Elizabeth. 2011).

\section{Kontiniutas Ketersediaan Pangan Pendukung Ketahanan Pangan}

Untuk menumbuhkan ekonomi perdesaan 
perlu upaya memperkuat jaringan sosial masyarakat dan kelembagaan (Elizabeth. 2008), baik dari aspek struktur atau konfigurasinya (sebagai jaringan yang efisien), peranan atau fungsi keanggotaan (tingkat partisipasi) masyarakat (dan petani) (pembagian kerja secara organik), maupun berperannya fungsi kearifan lokal (Elizabeth. 2019). Keseimbangan dan keberpihakan ekonomi masyarakat, terutama di pedesaan, terkait erat dengan upaya pengentasan kemiskinan di pedesaan, kemandirian pangan, dan mempengaruhi keberhasilan terwujudnya ketahanan pangan. Keterbatasan pendapatan petani (miskin dan berkekurangan) akibat relatif rendah dan tidak stabilnya produksi usahatani mengakibatkan keterbatasan ekonomi dan penghidupan di pedesaan. Hal tersebut mengindikasikan keterkaitan/ keeratan hubungan antara kontiniutas ketersediaan pangan dari stabilitas perolehan produksi dan produktivitas usahatani pangan terhadap pendapatan petani, dan stabilitas perekonomian di pedesaan.

Terjadinya anomali iklim ekstrem, tingginya degradasi dan konversi lahan yang tidak terkendali, dan berbagai kendala terkait lainnya diprediksi sangat mempengaruhi dan menjadi salah satu penyebab relatif rendahnya kapasitas dan ketersediaan pangan. Seiring peningkatan pertumbuhan penduduk yang rata-rata mencapai kisaran 1,49 persen menyebabkan peningkatan permintaan pangan. Harus dihadapinya berbagai permasalahan tersebut dalam upaya mewujudkan ketahanan pangan karena penambahan ketersediaan pangan masih lebih rendah dibanding pertumbuhan permintaannya. Sementara itu, pertumbuhan ekonomi sekitar 6-7 persen dan pendapatan pangan yang masih elastis. Kecukupan dan kemampuan mencukupi kebutuhan pangan masyarakat di pedesaan merupakan upaya dan program kebijakan pembangunan pertanian berkelanjutan dan yang secara berkelanjutan akan mewujudkan kemandirian serta ketahanan pangan nasional. Meski mengindikasikan keniscayaan dalam kesinambungannya bila pemerintah mengabaikan keberpihakan terhadap perekonomian masyarakat pertanian dan perdesaan.

\section{Terwujudnya Ketahanan Pangan Berkelanjutan}

Ketahanan pangan diartikan sebagai terpenuhinya kebutuhan pangan yang cukup (kualitas, kuantitas, dan gizi), yang diwujudkan melalui peran serta dan manajemen fungsi-fungsi penyediaan dan distribusi dan keterlibatan peran para pelaku usaha produksi, distribusi dan jasa dibidang pangan serta konsumsi pangan dan gizi. Ketersediaan dan kontiniutas bahan pangan serta pendapatan masyarakat/petani untuk meningkatkan kesejahteraan di pedesaan terkait erat dengan aspek kelembagaan pertanian, masyarakat dan perdesaan. Dengan menggarisbawahi cukup baiknya ketersediaan dan sangat mendukungnya potensi sumberdaya alam, tenaga kerja, dan lingkungan di wilayah pedesaan. Pentingnya kecukupan pangan mencerminkan keberpihakan pemerintah akan perbaikan keseimbangan ekonomi masyarakat untuk terwujudnya ketahanan pangan, meski kesinambungan dan keberlanjutannya masih suatu keniscayaan, nantinya.

Untuk mewujudkan ketahanan pangan berkelanjutan sebagai pencapaian keberhasilan program kebijakan pembangunan pertanian, didukung berbagai faktor, diantaranya:

1) Ketersediaan input untuk komoditaskomoditas yang baik untuk dikembangkan secara umum maupun spesifik lokasi, atau usaha dimana produsen dapat mengetahui banyaknya sumberdaya pertanian, variasi jenis produk serta mutu komoditas sangat memungkinkan diperoleh, dan didukung oleh sistem distribusi yang efektif dan efisien serta kena sasaran;

2) Sarana dan prasarana pendukung seperti: infrastruktur, transportasi, 
komunikasi, dan lain-lain dan tersedianya pangan yang sebagaian besar merupakan produksi sendiri baik dari hasil pertanian dan terait pertanian serta stabilitas dan kontinuitas ketersediaan pangan yang sangat cukup baik dan terjamin, aksesibilitas dan keterjangkauan pangan secara memadai dan kualitas konsumsi yang sehat dan aman di konsumsi oleh kalangan masyarakat pada umumnya;

3) Lembaga-lembaga pendukung modal usaha terkait pertanian, seperti: koperasi, perbankan dan lembaga keuangan dan pembiayaan lainnya yang mampu memfasilitasi pelayanan dari berbagai macam produk dengan spesifikasi pelayanan yang dibutuhkan untuk masing-masing unit atau kelompok usaha atau agribisnis;

4) Upaya menciptakan, meningkatkan, dan memanfaatkan (mengkonsumsi) diversifikasi pangan hasil usaha pertanian dan subsektor pertanian lainnya;

5) Kebijakan pemerintah yang mendukung pengembangan usaha, baik adanya kebijakan fiskal dan moneter serta peraturan dan perundang-undangan untuk mengatur hasil hasil produksi pertanian dan terkait lainnya sehingga dalam perjalanannya lancar;

6) Pendekatan dan pengkajian berbagai peraturan dan regulasi terkait, serta pendampingan yang lebih serius, mendalam dan berkelanjutan untuk pengadaan dan ketersediaan pangan untuk mewujudkan kemandirian pangan menuju ketahanan pangan berkelanjutan.

Upaya pencapaian ketahanan pangan berkelanjutan sangat diperlukan ketersediaan perangkat kebijakan yang memadai, teknologi dan informasi yang dibutuhkan (Elizabeth, R 2007a). Disamping itu, berfungsinya lembaga pendukung lainnya seperti: penyuluhan, pemasaran, dan sistem pendekatan instansi terkait (Elizabeth, R. 2009). Keberhasilan kinerja pembangunan pertanian tercermin pada tercapainya ketahanan pangan berkelanjutan, baik di daerah dan secara nasional.

Untuk menumbuhkan ekonomi perdesaan perlu upaya memperkuat jaringan sosial masyarakat dan kelembagaan, baik dari aspek struktur atau konfigurasinya (sebagai jaringan yang efisien), keanggotaan (tingkat partisipasi masyarakat), maupun peranan atau fungsi (pembagian kerja secara organik).

Partisipasi petani dan peran kearifan lokal sangat mempengaruhi keberhasilan pemberdayaan dan peningkatan peran, fungsi dan kinerja kelembagaan pertanian. Keikutsertaan peran kearifan lokal (local wisdom) dan partisipasi petani dalam peningkatan dan pemberdayaan kelembagaan pertanian merupakan salah satu strategi pemerintah untuk mendukung kemandirian dan ketahanan pangan berkelanjutan.

Keberpihakan berbagai pihak terkait dalam pengimplementasian berbagai inovasi teknologi pertanian untuk mengantisipasi penanganan pemenuhan pangan dengan dan meningkatkan partisipasi petani dan peran kearifan lokal dalam pemberdayaan berbagai kelembagaan pertanian.

Peran partisipasi dan kelembagaan pertanian yang mengikutsertakan kearifan lokal di suatu daerah, merupakan aset dalam mewujudkan keberhasilan pembangunan pertanian. Pengimplementasian berbagai inovasi teknologi pertanian untuk mengantisipasi penanganan pemenuhan pangan dengan dan meningkatkan partisipasi petani dalam pemberdayaan berbagai kelembagaan pertanian terkait dan kearifan lokal, membutuhkan keberpihakan berbagai pihak terkait.

Untuk mewujudkan kemandirian pangan menuju ketahanan pangan berkelanjutan 
dibutuhkan pendekatan dan pengkajian berbagai peraturan dan regulasi terkait, serta pendampingan yang lebih serius, mendalam dan berkelanjutan untuk pengadaan dan ketersediaan pangan.

\section{Kesimpulan}

Pertumbuhan ekonomi sekitar 6-7\% dan pendapatan pangan yang masih elastis, sementara itu pertumbuhan penduduk yang rata-rata mencapai kisaran 1,49\% menyebabkan peningkatan permintaan pangan. Dengan penambahan ketersediaan pangan masih lebih rendah dibanding pertumbuhan permintaannya, menimbulkan berbagai permasalahan dalam upaya mewujudkan ketahanan pangan sementara Peningkatan dan pemberdayaan peran kelembagaan pertanian merupakan salah satu strategi pemerintah untuk mendukung ketahanan pangan berkelanjutan.

Meningkat dan eksisnya kelembagaan pertanian mencerminkan kemampuan SDM dan kinerja petani, salah satunya dengan meningkatnya produksi dan produktivitas usahatani yang sangat mempengaruhi besar kecilnya pendapatan petani. Partisipasi petani dan kearifan lokal sangat mempengaruhi keberhasilan pemberdayaan dan peningkatan peran, fungsi dan kinerja kelembagaan pertanian. Perlunya petani secara berkelanjutan mendapat informasi, bimbingan dan pelatihan inovasi teknologi tepat guna, yang diperoleh baik melalui kelompok tani maupun melalui penyuluhan dari dinas terkait dengan pendampingan aktif dan berkesinambungan agar peran dan pengaruh tersebut akan lebih baik hasilnya dan berdayaguna. Perlunya keberpihakan berbagai pihak terkait dalam pengimplementasian berbagai inovasi teknologi pertanian untuk mengantisipasi penanganan pemenuhan pangan dengan dan meningkatkan partisipasi petani dalam pemberdayaan berbagai kelembagaan pertanian terkait dan kearifan lokal.

Perlunya pendekatan dan pengkajian berbagai peraturan dan regulasi terkait serta pendampingan yang lebih serius, mendalam dan berkelanjutan untuk mengurus pengadaan dan ketersediaan pangan untuk mewujudkan kemandirian pangan menuju ketahanan pangan berkelanjutan.

\section{Daftar Pustaka}

Altieri, M. A. (2004). Linking ecologists and traditional farmers in the search for sustainable agriculture. Frontiers in Ecology and the Environment, 2(1), $35-42$.

Arifin, B. (2004). Analisis ekonomi pertanian Indonesia. Kompas.

Asnuddin, A. (2010). Pendekatan partisipatif dalam pembangunan proyek infrastruktur Perdesaan di Indonesia. SMARTek, 8(3).

Elizabeth, R. 2011. Strategi Pencapaian Diversifikasi Dan Kemandirian Pangan Dalam Rangka Mewujudkan Ketahanan Pangan: Antara Harapan Dan Kenyataan. Buku IPTEK. Pusat Penelitian dan Pengembangan Tanaman Pangan.Badan Litbang Pertanian. Kementerian Pertanian.

Elizabeth, R. 2008. Diagnosa Kemarjinalan Kelembagaan Lokal untuk Menunjang Perekonomian Rakyat di Pedesaan. Jurnal SOCA. Vol. 8. No. 2. Juli 2008. hal. 58-64. Jur. Sosial Ekonomi Pertanian. Universitas Udayana. Bali.

Elizabeth, R. 2007b. Penguatan dan Pemberdayaan Kelembagaan Petani Mendukung Pengembangan Agribisnis Kedelai. Prosiding Seminar Nasional. Dinamika Pembangunan Pertanian dan Perdesaan: Mencari Alternatif Arah Pengembangan Ekonomi Rakyat. Pusat Sosial Ekonomi dan Kebijakan Pertanian (PSE-KP). Bogor. Badan Litbang Pertanian. Departemen Pertanian. Jakarta.

Elizabeth, R. 2007a. Fenomena Sosiologis 
Metamorphosis Petani: Ke Arah Keberpihakan Masyarakat Petani Di Perdesaan Yang Terpinggirkan Terkait Konsep Ekonomi Kerakyatan. Forum Agro Ekonomi (FAE) Vol. 26. Juli 2007. PSE-KP. Bogor. Badan Litbang Pertanian. Departemen Pertanian. Jakarta.

Elizabeth. E. 2007. Reorientasi dan Peran Kearifan Lokal Dalam Akselerasi Inovasi Sistem Integrasi Tanaman Ternak mendukung Ketahanan Pangan di Pedesaan. Keamanan Produk Pangan Hewani di Indonesia. Prosiding Nasional Hari Pangan Sedunia XXVII Dukungan Teknologi untuk Meningkatkan Produk Pangan Hewani dalam Rangka Pemenuhan Gizi Masyarakat. Badan Penelitian dan Pengembangan Pertanian. Departemen Pertanian, Bogor, 21 Nopember 2007, hal. 139-153.

Mahmuddin. 2013. Paradigma Pembangunan Pertanian: Pertanian Berkelanjutan Berbasis Petani Dalam Perspektif Sosiologis. Jurnal Sosiologi Univ. Syiah Kuala. Vol.3. No.3. Juni 2013.

Mosher, A. T. (1978). Pembangunan Pertanian. PT. Yasa Guna Jakarta.

Pranadji, T. (2016, September). Partisipasi petani dalam program pengembangan teknologi tanaman pangan. In Forum penelitian Agro Ekonomi (Vol. 3, No. 1, pp. 28-35).

Wilken, G. C. (1990). Good farmers: Traditional agricultural resource management in Mexico and Central America. Univ of California Press. 